\title{
Sustainable Development Through People's Participation in Resource Management
}

The United Nations Research Institute for Social Development (UNRISD) is conducting a research programme on 'Sustainable Development through People's Participation in Resource Management', which is designed to address issues raised by the current debate on sustainable development. It builds upon the Institute's earlier work on participation in development, which defined such participation as 'the organized efforts to increase control over resources and regulative institutions in given social situations, on the part of groups and movements of those hitherto excluded from such control'.

The current research seeks to contribute to an understanding, not only of the ways in which local individuals contribute to the success of conservation projects funded by outside donors, but also of the ways in which people take sustainable development into their own hands - either by working to maintain their traditionally sustainable resource management systems, or by acting to resist projects or policies which will adversely affect their livelihood by degrading the environment. Reports have already been published of studies conducted in Ethiopia, Tanzania, northern Mexico, and India, while studies are under way in southern Mexico, Sudan, northeastern Tanzania, the African drylands, the Philippines, Ghana, Solomon Islands, Senegal, the Himalayas, Brazil, and the Amazon region.

As part of the research programme, a survey of literature is currently being conducted on 'grassroots' participation in environmental conservation or sustainable resource management projects in developing countries. Specifically, information on case-studies is being gathered under the following broad categories:

1) Resistance to, and popular movements to counter, environmentally destructive, externally-planned infrastructure, including unsuitable commercial or development projects;

2) 'Grassroots' participation in conservation projects initiated from within or outside the local community; and
3) Traditional/indigenous natural resource management systems that are threatened by internal or external factors, but could be successfully adapted for present-day use.

Cross-referenced key words or phrases include agroforestry, deforestation, desertification, indigenous technology, irrigation, resource-use study, social equality, soil erosion, urban environment, vulnerable groups, and women.

The above research is being undertaken in coordination with related UNRISD research on the environment. The 'Social Dynamics of Deforestation' programme includes national and regional analysis of the implications of deforestation for the livelihood and living conditions of poverty groups in urban and rural areas. Individual, family, and group, reactions and strategies to combat the adverse effects of environmental degradation are assessed, as are interactions with other key factors such as agencies of the state, modern commercial interests, nongovernmental organizations, and 'grassroots' movements.

The UNRISD research programme on 'Women, Environment, and Population' is conducting micro-level empirical research to investigate the relationships of different forms of environmental degradation with women's time-use patterns and activities, as well as with morbidity and mortality, and with fertility and migration decisions. Studies are under way in Kenya, Malaysia, and Mexico.

Inquiries about the 'Sustainable Development and People's Participation in Resource Management' casestudies, UNRISD research programmes, and available publications, should be addressed to the undersigned:

\section{ADRIENNE CRUZ \\ UN Research Institute for Social Development Palais des Nations \\ CH-1211 Geneva 10, Switzerland.}

\section{Scientists' Institute for Public Information: Global Change Program}

We live on an interconnected, interdependent, living planet. Events taking place in one part of the world affect people living thousands of kilometres away. In no other time has this fact been as evident as in the 20th century, with its advances in communications technology and everincreasing human population and enlightenment.

In recent years, the survival of our planet has attracted the attention of policymakers, the media and, increasingly, the public. In order to make informed decisions about appropriate technologies, natural resource management, and the future of the planet, the public relies primarily on the media for increased awareness and understanding of these intricate scientific issues.

Without access to accurate, truly scientific information, the media cannot present a reliable picture of these often controversial issues. SIPI's Media Outreach Program on Global Change provides journalists with greater access to scientific expertise in an effort to help them inform the public more accurately than hitherto about our changing environment.

The primary components of the Global Change Program are the International Hot-line and Global Change Media Briefings.

\section{International Hot-line}

In 1980, SIPI began operating the Media Resource Service (MRS), a free referral service for journalists who need information sources in science, technology, medicine, and the environment. The International Hot-line, begun in 1989 , is an extension of this service, providing assistance to environmental reporters world-wide.

Journalists can call the Hot-line by reversing the charges, faxing their inquiries, or contacting their US bureaus. A brief description of the story which the journalist is working on, the desired locale of the expert(s), languages spoken, and their deadline, will provide guidelines for a staff person to search the data-base for appropriate experts. When once the experts are identified, the staff person provides the journalist with names, affiliations, and telephone/fax numbers.

In addition to US and Canadian environmental experts, scientists from over 45 countries - including developing and industrialized countries, and representing government, academia, and non-governmental organizations - have agreed to respond to media inquiries on a broad range of environmental topics ranging from air pollution to water quality, and from land erosion to marine pollution. 


\section{Global Change Media Briefings}

Environmental issues are, far too often, inherently controversial and lacking in simple solutions. How does one weigh the feasibility of building a dam to provide hydroelectric power against the possibility of destroying a river's fragile ecocomplex and its component ecosystems valued resources for generations? Or clear-cutting a forest to create farmland, resulting in the destruction of a natural habitat? Or importing hazardous waste to boost the local economy to the possible detriment of children's health?

Although most environmental issues, such as solid waste or water pollution, share some universality of nature, each nation and even each community has a unique perspective that needs to be addressed. SIPI's Global
Change Media Briefings provide a forum for in-depth discussion of the questions surrounding environmental controversies.

These briefings, featuring a panel of experts, present an opportunity for international and US journalists to learn about possible solutions to each other's environmental problems. Particular attention is paid to the dilemmas faced by developing nations.

\section{Roshi Pelaseyed, Director Global Change Program Scientists' Institute for Public Information 355 Lexington Avenue New York, NY 10017, USA.}

\section{Royal Leadership and Awards for the Ageing}

Age Resource and The National Council on Ageing, under the auspices of Age Concern England, are proud to announce that HRH The Prince of Wales has kindly agreed to be Age Resource's first President. Age Resource is a partnership between major organizations in the field of ageing and other nationally-known groups working in different areas through which the skills and experience of older people can make a valuable contribution. In such matters Britain once again stands out as something of a world leader.

The founding organizations include the two largest of their kind in the United Kingdom, namely the British Trust for Conservation Volunteers and the Royal Society for Nature Conservation. The Retired Executive Action Clearing House (REACH) and Shell UK are also participating.

\section{Origins and Objectives}

Age Resource came into being through the energies of a small group of people from Age Concern England and Shell UK, getting together with Robert Boote, CVO, first Director-General of the British Nature Conservancy Council. With an influential and committed group of patrons and under Robert Boote's energetic chairmanship, Age Resource believes that large numbers of older people have the will and enthusiasm, as well as the skills and ability, to contribute to society's environmental and conservational needs.

One of the initial schemes of Age Resource has been the setting up of three pilot projects - in Essex, Sussex, and Lancashire - to encourage the greater involvement of older people in environmental ventures, together with linked research and evaluation. A review of current and potential research activities is under way, with the collaboration of the Carnegie Inquiry into the Third Age, the Volunteer Centre UK, the Age Concern Institute of
Gerontology, REACH, and the Community Development Foundation.

When once Age Resource has become firmly established in Great Britain, it is hoped that it will be expanded across Europe, by which time its initiative should serve as a model for the rest of the world.

\section{Age Resource Awards}

Age Resource believes that 'you get out of life what you put into it', and so they have established the Annual Age Resource Awards (sponsored by Shell UK) to identify the enormous contribution which older people can, and in some cases do, make to life in the UK today. Last year the winners in its six categories inspired thousands of people, of 50 years of age or older, with their activity, enthusiasm, and often unique projects.

This year (1991) Age Resource extended the $£ 1,000$ Awards to nine categories covering three areas of Voluntary Work (Education, Caring, and Enhancing the Environment), as well as Personal Development, Selfhelp in the Community, Intergenerational Activity (schemes which bring together older and younger people for their mutual benefit), Campaigning, and Employment, the ninth Award being an open category which involves schemes that do not fit into anything else and thus completes some coverage of just about everything!

The closing day for this year's competition has passed but it is hoped to extend the scheme still further in 1992 and hold the award-winning ceremony again at the Royal Festival Hall in London.
ENID IRVING, Editor
Age Resource Newsletter
National Council on Ageing
Astral House, 1268 London Road
London SW16 4ER
England, UK.

\section{Circumpolar 'Ecosystems' in Winter}

On Friday, 16 February 1990, much confusion resulted from weather delays in Vancouver and Toronto. The travel people at North Star Tours managed to delay the Winnipeg-Churchill flight in order to pick up stragglers coming out of Toronto and elsewhere. However, those people who were many hours late getting into Winnipeg (flying with that other airline) were flown to Thompson and placed on a waiting train to Churchill. These problems were anticipated in advance (as we had planned for northern weather problems) and thanks to North Star, Canadian Airlines, and VIA Rail, we managed to keep running smoothly.
The Symposium got under way with a tour of CNSC and the 'Sundown Walkabout' during one of the warmest days that week, a balmy $-34^{\circ} \mathrm{C}$ with a wind-chill equivalent to somewhere near double this value $\left(-70^{\circ} \mathrm{C}\right)$. During the Walkabout there was a full-dress display ranging from seal and caribou (Rangifer $\mathrm{sp}$.) all the way to synthetics. The two Arctic Foxes (Alopex lagopus) that came on the Walkabout with us insisted on staying for dinner as well. While we struggled through our Char (Salvelinus alpinus) dinner with Manitoba Wild Rice (Zizania palustris) and French wines, the Centre managed to sell 86 tickets for a draw including Kaufman Sorel 